Kong. Res. J. 4(1) : 65-68, 2017 ISSN 2349-2694

Kongunadu Arts and Science College, Coimbatore.

\title{
PHYSICO-CHEMICAL STATUS OF POLACHIRA WETLAND ECOSYSTEM IN SOUTHERN KERALA
}

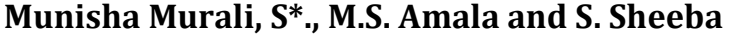 \\ Department of Botany, Sree Narayana College, Kollam -691 001. \\ *E.mail: munishamurali@yahoo.co.in
}

\begin{abstract}
Polachira wetland in Southern Kerala is a famousdestination of itinerant birds.Thebird aggregation in wetlands is always correlated to the abiotic and biotic factors of the ecosystem. The present investigation reveals the hydrology of the Polachirawetland during February to July 2014. The air and water temperature agreed with the climatic factors prevailed. The $\mathrm{pH}$ showed slight acidity and alkalinity. The total solids fluctuation was renderedby the Total Suspended Solid and Total Dissolved Solid which was indicated by organic discharge, high chloride content and salinity in water. Salinity in water was elevated due to the incursion of saline water from Paravur estuary to Polachira wetland through a canal. The free carbondioxide concentration did not show much variation but dissolved oxygen showed variation. The total hardness which was related to the calcium and magnesium hardness in water was determined.Alkalinity was balance in the ecosystem. Nutrients such as nitrite, nitrate, phosphate and silicate were in equilibrium concentration.Correlations of physicochemical parameters among six months were statistically significant.
\end{abstract}

Keywords: Polachirawetland, hydrology, nutrients.

\section{INTRODUCTION}

Wetlands are unique landscape which abode a great biodiversity. These ecotonesare saturated with countless forms of species of great ecological importance. This sensitive system preserves both aquatic and terrestrial ecosystems.In wetland the species richness is always enveloped around the hydrological regime of the environment. Nowadays anthropogenic input is elevating beyond a certain threshold level which has a profound impact on the water quality of the aquatic environment.India sustains assorted types of wetlands strewn across various eco- geographical regimes that comprises of wetlands in high altitude Himalayas to Deccan plateau.Kerala is bestowed with the most productive wetlands. Wetlands in Kerala are facing dwindling of ecological and economical valuesdue to high populace.The present investigation has been taken up the variations in the hydrology of Polachira wetland in Southern Kerala.

\section{MATERIALS AND METHODS}

The present study was carried out on the physico-chemical parameters of Polachira Wetland $\left(8^{\circ} 50^{\prime} 26.89^{\prime \prime} \mathrm{N}\right.$ and $\left.76^{\circ} 42^{\prime} 0.3^{\prime \prime} \mathrm{E}\right)$ located in the Southern part of Kollam district in Kerala.The sprawling wetland spread over 600 hectares is on theem bankment of estuaries of the Ithikkara River and Paravur backwaters.It is an oval shape wetland at a depth of $1 \mathrm{~m}$ below ground level and is encircled by small creeks and is densely vegetated. The samples were collected from five stations in the second week of every month during a period from February 2014 to July 2014. Physical parameters like Temperature and $\mathrm{pH}$, were performed on the field. The physicochemical parameters like Total Solids (TS), Total Dissolved Solids (TDS), Total Suspended Solids (TSS), Dissolved $\mathrm{O}_{2}$, Free carbon dioxide, Total alkalinity, Total hardness, Calcium hardness, Magnesium hardness, Chloride, Salinity, Phosphate, Sulphate, Nitrite and Nitrate were analyzed as per the methods of APHA (1998) and Trivedy and Goel (1986). Data collected were subjected to proper statistical analysis. One-way analysis of variance (ANOVA) and Pearsoncorrelation coefficient was calculated to test the degree of relationship of water quality parameters between six months.

\section{RESULTS AND DISCUSSION}

The monthly variation (average value of different stations) of physicochemical parameters is given in Table 1 . The temperature of both air and water is a remarkable regulatory factor governing the biogeochemical reactions of aquatic ecosystem. Monthly variation of atmospheric temperature in Polachira wetland ecosystem ranged between $30.1^{\circ} \mathrm{C}$ and $36.6^{\circ} \mathrm{C}$ during the month of June and March respectively.The present investigation revealed well marked variations in the atmospheric temperature. This may be due to the climatic conditions. Water temperature ranged from $29.6^{\circ} \mathrm{C}$ (July) to $33.4^{\circ} \mathrm{C}$ (March). The maximum and minimum temperatures may be due to the hot and cold climatic conditions. 
Table 1. Monthly variation of physico-chemical parameters of Polachira wetland ecosystem during February to July, 2014.

\begin{tabular}{|c|c|c|c|c|c|c|c|}
\hline Sl No & Parameters & FEB & MAR & APR & MAY & JUN & JULY \\
\hline 1 & Atmospheric Temp. $\left({ }^{\circ} \mathrm{C}\right)$ & 31.4 & 36.6 & 32.2 & 35.3 & 30.1 & 33.8 \\
\hline 2 & Water Temp. $\left({ }^{\circ} \mathrm{C}\right)$ & 31.8 & 33.4 & 31.6 & 32.8 & 30.4 & 29.6 \\
\hline 3 & $\mathrm{pH}$ & 6.63 & 7.23 & 5.88 & 8.28 & 6.34 & 5.97 \\
\hline 4 & Total Solid (mg/L) & 1420 & 960 & 2160 & 900 & 740 & 560 \\
\hline 5 & Total Suspended Solid(mg/L) & 460 & 320 & 500 & 360 & 280 & 220 \\
\hline 6 & Total Dissolved Solid (mg/L) & 780 & 640 & 1680 & 540 & 460 & 340 \\
\hline 7 & Dissolved $\mathrm{O}_{2}(\mathrm{mg} / \mathrm{L})$ & 4 & 3.4 & 4.08 & 3.6 & 6.3 & 3.9 \\
\hline 8 & Free $\mathrm{CO}_{2}(\mathrm{mg} / \mathrm{L})$ & 15.14 & 15.1 & 17.03 & 14.64 & 15.36 & 14.12 \\
\hline 9 & Total Alkalinity (mg/l) & 101 & 76 & 74 & 71 & 101 & 72 \\
\hline 10 & Hardness $\left(\mathrm{mg} / \mathrm{L} \mathrm{CaCO}_{3}\right)$ & 364 & 380 & 300 & 292 & 276 & 160 \\
\hline 11 & Ca Hardness $\left(\mathrm{mg} / \mathrm{L} \mathrm{CaCO}_{3}\right)$ & 41.022 & 96.162 & 85.762 & 60.9 & 68.932 & 46.49 \\
\hline 12 & Mg Hardness (mg/L $\left.\mathrm{CaCO}_{3}\right)$ & 50.692 & 34.136 & 20.476 & 21.442 & 25.342 & 10.712 \\
\hline 13 & Chloride (mg/L) & 360.78 & 202.74 & 1177.8 & 760.38 & 864.76 & 536.76 \\
\hline 14 & Salinity (ppt) & 0.6636 & 0.3870 & 2.1038 & 1.369 & 1.5548 & 0.9751 \\
\hline 15 & Nitrite (ppm) & 0.0538 & 0.0057 & 0.0148 & 0.08368 & 0.0678 & 0.0516 \\
\hline 16 & Nitrate (ppm) & 0.0536 & 0.0465 & 0.1399 & 0.7863 & 0.1899 & 0.1306 \\
\hline 17 & Phosphate (ppm) & 0.0213 & 0.0177 & 0.0889 & 0.0174 & 0.0294 & 0.0296 \\
\hline 18 & Silicate (ppm) & 16.013 & 12.787 & 12.1688 & 14.513 & 14.361 & 14.076 \\
\hline
\end{tabular}

Table 2. Analysis of Variance of physico-chemical characteristics of Polachira wetland ecosystem during February - July, 2014.

One factor ANOVA

\begin{tabular}{llll}
\hline Mean & $n$ & Std. Dev & \\
\hline 204.626 & 18 & 372.7767 & FEB \\
156.556 & 18 & 265.3550 & MAR \\
339.075 & 18 & 649.0492 & APR \\
173.173 & 18 & 283.5576 & MAY \\
162.263 & 18 & 266.3045 & JUN \\
113.812 & 18 & 182.8021 & JULY \\
191.584 & 108 & 366.9605 & Total \\
\hline
\end{tabular}

\begin{tabular}{lllllr}
$\begin{array}{l}\text { ANOVA } \\
\text { table }\end{array}$ & & & & & \\
\hline Source & $S S$ & $d f$ & $M S$ & $F$ & $p$-value \\
\hline Treatment & $547,158.8997$ & 5 & $109,431.77993$ & 0.81 & .5485 \\
Error & $13,861,463.1610$ & 102 & $135,896.69766$ & & \\
\hline Total & $14,408,622.0606$ & 107 & & & \\
\hline
\end{tabular}


Table 3. Correlation matrix of physico-chemical characteristics of Polachira wetland ecosystem during February - July, 2014.

Correlation Matrix

\begin{tabular}{|c|c|c|c|c|c|}
\hline$F E B$ & 1.000 & & & & \\
\hline$M A R$ & .987 & 1.000 & & & \\
\hline$A P R$ & .950 & .930 & 1.000 & & \\
\hline$M A Y$ & .902 & .873 & .950 & 1.000 & \\
\hline JUN & .812 & .778 & .898 & .983 & 1.0 \\
\hline$J U L Y$ & .869 & .834 & .936 & .996 & .99 \\
\hline & 18 & \multicolumn{4}{|c|}{ sample size } \\
\hline & $\begin{array}{l} \pm \\
.468\end{array}$ & \multirow{2}{*}{\multicolumn{4}{|c|}{ critical value .05 (two-tail) }} \\
\hline & $\begin{array}{l} \pm \\
.590\end{array}$ & & & & \\
\hline
\end{tabular}

$\mathrm{pH}$ showed a minimum and maximum value of 5.88 and 8.28 during the month of April and May. It is found that a slight acidic as well as basic in water may be induced by the improper use of fertilizers from agriculture field and garbage disposal.

The Total solids (TS) are a measure of both, the dissolved as well as suspended solids in watercomprising dissolved salts, suspended particles, soil particles, discharged effluents and decomposed organic matter (Patil et al., 2011). In the present study the total solid varied between 560 $\mathrm{mg} / \mathrm{L}$ (July) and $2160 \mathrm{mg} / \mathrm{L}$ (April). The total suspended solid was measured between $220 \mathrm{mg} / \mathrm{L}$ (July) and $500 \mathrm{mg} / \mathrm{L}$ (April). The total solid and total suspended solid may be resulted from the run-off water, which carries dissolved solids and also organic wastes from garbage dumping, agricultural land, waste water discharges and algal growth. A similar observation was reported by Chennakrishnan et al. (2008). A minimum total dissolved solid of $340 \mathrm{mg} / \mathrm{L}$ was observed in July and a maximum of $1680 \mathrm{mg} / \mathrm{L}$ was during the month of April.Presence of high TDS may be due to the high chloride and salinity contributed by the intrusion of saline water from Paravur estuary to Polachira wetland through a canal.
Oxygen content is a major parameter needed by aquatic life forms. The dissolved $\mathrm{O}_{2}$ measured a lowest concentration of $3.4 \mathrm{mg} / \mathrm{L}$ in the month of March and the highest concentration of 6.3 $\mathrm{mg} / \mathrm{L}$ observed during the month of June.Low oxygen concentrations are generally associated with heavy contamination of organic matter. In such conditions oxygen, sometimes, totally disappears from the water (Trivedy and Goel, 1986). Monthly variation of free $\mathrm{CO}_{2}$ concentration ranged between $14.12 \mathrm{mg} / \mathrm{L}$ (July) and $17.03 \mathrm{mg} / \mathrm{L}$ (April).The wetland received more organic matter through surface run off and drainage and its decomposition might have resulted in the liberation of more amounts of $\mathrm{CO}_{2}$ in the water column. The free $\mathrm{CO}_{2}$ concentration change may be due to the micro bacterial activities, increase in temperature and biochemical reactions.

Alkalinity is a measure of acid present in water and of the cations balanced against them (Yogesh Shastri and Pendse, 2001). The presence of total alkalinity during the investigation period showed a fluctuation between $71 \mathrm{mg} / \mathrm{L}$ in May and $101 \mathrm{mg} / \mathrm{L}$ during the month of February and June respectively. The increase in total alkalinity was found to be associated with the rainfall and the subsequent surface run off and leaching. 
The level of hardness was estimated between $160 \mathrm{mg} / \mathrm{L} \mathrm{CaCO}_{3}$ and $380 \mathrm{mg} / \mathrm{L} \mathrm{CaCO}_{3}$ during the month of July and March. High values of hardness are probably due to regular addition of large quantities of sewage and detergent into wetland from the nearby residential localities. Trivedi and Goel (1986) and Singh and Mahajen (1987) are of the view that the high hardness is suggestive of pollution due to domestic waste and industrial effluents. The calcium hardness value was recorded between a minimum of $41.022 \mathrm{mg} / \mathrm{L} \mathrm{CaCO}_{3}$ (February) and a maximum of $96.162 \mathrm{mg} / \mathrm{L} \mathrm{CaCO}_{3}$ (March). The amount of calcium increase may be due to rapid oxidation/decomposition of organic matter.

Monthly variation of magnesium hardness recorded between $10.712 \mathrm{mg} / \mathrm{L} \mathrm{CaCO}_{3}$ (July) and $50.692 \mathrm{mg} / \mathrm{L} \mathrm{CaCO}_{3}$ (February). Magnesium also occurs in all kinds of natural waters with calcium, but its concentration remains generally lower than the calcium (Trivedy and Goel, 1986).

Chloride is one of the factor governing the biota of aquatic system. The chloride content recorded lowest value of $202.74 \mathrm{mg} / \mathrm{L}$ (March) and maximum rate of $1177.8 \mathrm{mg} / \mathrm{L}$ (April). High and low chloride concentration was coincided with the salinity. The salinity ratewas measured between 0.3870 ppt (March) and 2.1038 ppt (April). Higher salinity content was due to the connection of Polachira wetland with Paravurestuary through a canal.

The nitrite content showed a variation between $0.0057 \mathrm{ppm}$ and $0.0836 \mathrm{ppm}$. Presence of even a small quantity of nitrite will indicate the organic pollution and the availability of partially oxidized nitrogenous matter (Trivedy and Goel, 1986). The average nitrate concentration was measured between 0.0465 ppm (March) and 0.7863 ppm (May). The low rate of nitrite and nitrate concentration may be due to the utilization by the phytoplankton which was abundant during March. The increase in nitrate concentration may be due to the decaying of organic materials, discharge of sewage, natural runoff and agricultural wastes.

Phosphate is the nutrient considered to be the critical limiting nutrient causing eutrophication offresh water systems (Rabalais, 2002). The variation of phosphate concentration was between 0.0174 ppm (May) and 0.0296 ppm (July). The presence of phosphate in the wetland may be due to surface runoff during rainy season receiving huge quantity of domestic sewage, cattle dung and detergents from the surrounding catchment area. Monthly variation of silicate concentration showed a minimum of $12.168 \mathrm{ppm}$ (April) and maximum of 16.013 ppm (February). High silicate content may be due to the soil erosion from catchment area.Analysis of variance of physico-chemical parameters during February to July 2014 showed that there is no significant difference in the mean value among months (Table 2). All correlations among six months were statistically significant (Table 3).

\section{CONCLUSION}

The monthly variations in physicochemical characteristics of Polachira wetland are providing a vivid knowledgeregarding the ecological status of wetland. This wetland is a preferred safe haven for resident and migratory birds. A frequent and continuous evaluation of this ecosystem is necessary to avoid dwindling of the resources.

\section{REFERENCES}

APHA, (1998). Standard methods for the examination of water and waste waters

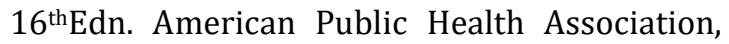
Washington D.C.

Chennakrishnan, C., A. Stephen, T. Manju and T. Raveen, (2008). Water Quality Status of Three Vulnerable freshwater Lakes of Suburban Chennai, India. Indian J. Environ. Ecoplan. 15: 591-596.

Patil, J.V., A.P. Ekhande and G.S. Padate, (2011). Study of Lotus Lake: Its abiotic factors their correlation with reference to seasonal changes and altitude. Ann. Biol. Res. 2: 44-56.

Rabalais, N. (2002). Nitrogen in Aquatic system. Ambio. 31: 102-112.

Singh, T. and I. Mahajen, (1987). Some physicochemical factors and phytoplankton of Ravalsarlake, Himachal Pradesh, Geobios. 14(10): 6-9.

Trivedy, R.K. and P.K. Goel, (1986). Chemical and Biological Methods for Water Pollution Studies. Environmental Publications, Karad (India).

Yogesh Shastri and D.C. Pendse (2001). Hydrobiological study of Dahikhuta reservoir. J. Environ. Biol. 21: 67-70. 